\title{
Projetos de futuro de jovens universitários do Distrito Federal: um estudo de caso
}

\author{
Raisa Maarit Pauliina Ojala
}

Curso: Doutorado em Sociologia

Data da defesa: 9 de junho de 2008

Orientador: Prof. Dr. Carlos Benedito Martins

\section{Resumo}

A presente tese de doutorado insere-se no campo de sociologia de juventude. O seu tema foca os estilos e projetos de vida de jovens estudantes universitários nas duas universidades em Brasília, Distrito Federal: a Universidade de Brasília (UnB) e a Universidade Católica de Brasília (UCB). Três cursos diferentes foram escolhidos para a pesquisa empírica. São estes: Pedagogia, Física e Direito. O principal objetivo da pesquisa era saber como é a vida dos jovens universitários no Distrito Federal. Estudou-se a relação deles com atividades políticas e movimentos culturais, como são suas famílias, que tipo de família pretendem construir no futuro e quais são seus planos profissionais. Os resultados da pesquisa incluem a conclusão de que os jovens diferem em termos de condição socioeconômica em relação aos planos de futuro profissional. Os jovens das camadas mais altas da sociedade procuram se realizar sem se preocupar com a sobrevivência, enquanto os estudantes de origem social inferior procuram estabilidade. Quanto aos papéis na futura família, além das diferenças socioeconômicas, os jovens diferem em termos de gênero. Nas futuras famílias, os de origem mais confortável começam a repensar os papéis sociais e as diferenças entre os gêneros não se destacam. Já os jovens de origem menos privilegiada 
reproduzem na futura família os papéis sociais tradicionais, sendo que a mãe-esposa, neste caso, abre mão da sua realização pessoal. Já em relação à participação política, a atitude crítica foi comum em todos os grupos pesquisados. Entretanto, a sua atuação difere significativamente das gerações anteriores.

Palavras-chave: ensino superior, juventude, projetos de futuro. 